\title{
MINERAL RESOURCE POTENTIAL OF THE COHUTTA WILDERNESS \\ AND THE HEMP TOP ROADLESS AREA, NORTHERN GEORGIA AND SOUTHEASTERN TENNESSEE
}

By

Jacob E. Gair ${ }^{1}$, Gertrude C. Gazdik ${ }^{2}$, and Maynard L. Dunn, Jr. ${ }^{2}$

\section{STUDIES RELATED TO WILDERNESS}

Under the provisions of the Wilderness Act (Public Law 88-577, September 3, 1964) and the Joint Conference Report on Senate Bill 4, 88th Congress, the U.S. Geological Survey and the U.S. Bureau of Mines have been conducting mineral surveys of wilderness and primitive areas. Areas officially designated as "wilderness," "wild," or "canoe" when the act was passed were incorporated into the National Wilderness Preservation System, and some of them are presently being studied. The act provided that areas under consideration for wilderness designation should be studied for suitability for incorporation into the Wilderness System. The mineral surveys constitute one aspect of the suitability studies. The act directs that the results of such surveys are to be made available to the public and be submitted to the President and to the Congress. This report discusses the results of a mineral survey of the Cohutta Wilderness and the Hemp Top Roadless Area in the Chat tahoochee National Forest, Fannin, Gilmer, and Murray Counties, Georgia, and the Cherokee National Forest, Polk County, Tennessee. The Cohutta Wilderness was established by Public Law 88-577, September 3 , 1964. Hemp Top Roadless Area was classified as a further planning area during the Second Roadless Area Review and Evaluation (RARE II) by the U.S. Forest Service, January 1979.

\section{SUMMARY}

The Cohutta Wilderness and the Hemp Top Roadless Area have minor occurrences of metallic minerals, but no known resource potential for such minerals in the forseeable future, judging by available data, and only a very minor potential for stone for aggregate, road construction, and similar nondimension use. The rocks of the Ducktown massive sulfide district to the northeast do not appear to extend into the study area, and geochemical data derived from samples of rock, soil, and alluvium do not reveal any anomalously high concentrations of trace elements that could be representative of hidden mineral deposits. Sedimentary rocks underlying the metamorphic rocks exposed at the surface have an unknown potential for hydrocarbons in the form of natural gas. No reasonable estimate of the potential can be made until some test drilling is done in the area.

\section{INTRODUCTION}

The Cohutta Wilderness and the Hemp Top Roadless Area are in the western part of the Blue Ridge physiographic province of northern Georgia and southeastern Tennessee. Except for about 1,460 acres at the northern extremity of the Cohutta Wilderness, all of the study area is in Georgia. The area of Cohutta Wilderness is 34,650 acres; that of Hemp Top is 2,800 acres. The study area is in rugged mountainous terrain, a strongly dissected upland ranging in altitude from about 980 to $4,200 \mathrm{ft}(300$ to $1,200 \mathrm{~m})$ above sea level. Local altitude differences of $1,450-2,000 \mathrm{ft}$ and slopes steeper than
25 degrees are common. The north end of the Cohutta Wilderness is about $6 \mathrm{mi}$ south of the Ocoee River gorge, 10 $\mathrm{mi}$ west-southwest of the major copper- and sulfurproducing district at Ducktown, Tenn., and about $22 \mathrm{mi}$ southeast of Cleveland, Tenn. (about $10 \mathrm{mi}$ west of the junction of U.S. Highways $4 \mathrm{ll}$ and 64, fig. 1). The eastern, central, and northwestern parts of the wilderness are drained by Jacks River and its tributaries; the southwestern part by the Conasauga River and its tributaries; and the Hemp Top Roadless Area, by Tumbling Creek and some of its western tributaries (see mineral resource potential map accompanying this report). All drainage ultimately goes to the Ocoee River, and from there into the Hiwassee River.

The topography is characterized by long, northtrending ridges and shorter diverging spurs. The principal ridges are Blue Ridge, Rough Ridge, and Cohutta Mountain. Jacks River forms a deep valley between Blue and Rough Ridges in the southeast part of the wilderness, but in the north-central part of the area, the river turns westward, truncating Rough Ridge. West of Cohutta Mountain the land surface drops off to the valley of the Conasauga River near the western boundary. Big Frog Mountain, the highest (4200 $\mathrm{ft}$ ) and most conspicuous point in the area, is on the ridge that forms the northern boundary.

About half of the area is bounded by U.S. Forest Service secondary roads. Access to these is by a network of Forest Service roads from U.S. Routes 64 , on the north, 411 , on the west, 76 , on the south and southeast, and Georgia Route 5 and Tennessee Route 68 on the northeast (fig. 1). Georgia Route 2 (East Cowpen Road), which is shown on road maps as bisecting the area, is no longer maintained in the wilderness and is virtually impassable. There are good trails along the tops of major ridges, and along Jacks River and some of its tributaries. A service road open only to hikers enters Beech Bottom in the north-central part of the wilderness. Trails are not present along most of the streams and ridges we followed.

\section{Previous Work}

Previous geologic studies of the environs of Cohutta Wilderness have been done by Safford, $(1856,1869)$, Salisbury (1961), Hernon (1968), Hurst $(1955,1973)$, C. E. Merschat and L. S. Wiener (unpub. data, 1973), and Slack and others (in press). Field trip guides for the Ocoee River gorge were prepared by Hurst and Schlee (1962) and Wiener and Merschat (1978). Only a study by Mellen (1956) was done directly in parts of the wilderness. The definitive work on the Ocoee Supergroup-the rocks underlying the study area-was done in the Great Smoky Mountains (King and others, 1958; Hamilton, 1962; Hadley and Goldsmith, 1963; King, 1964; Neuman and Nelson, 1965). Mineral resource studies in the vicinity of the wilderness include reports on base-metal sulfides, gold, iron and manganese, sulfur, and talc (Ashley, 1911; Furcron, 1960; Fureron and others, 1947; Hale, 1974; Haseltine, 1924; Hull and others, 1919; Hurst and Crawford, 1970; Kinkel and others, 1968; Magee, 1968; Maher, 1964; and Rove, 1926).

${ }^{2}$ U.S. Bureau of Mines 


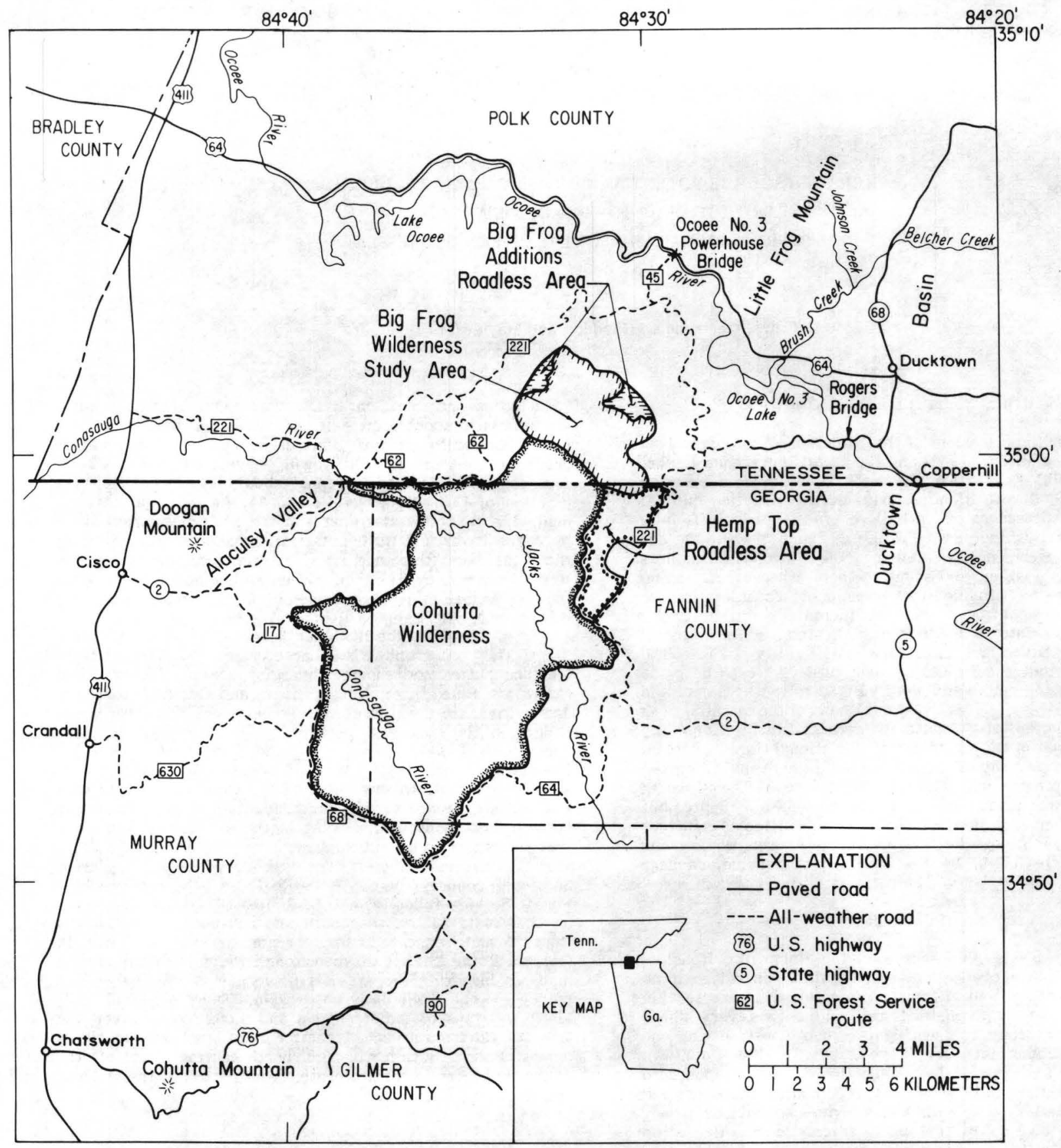

Figure 1.--Index map showing location of Cohutta Wilderness and Hemp Top Roadless Area. 
G. C. Gazdik and M. L. Dunn, Jr., assisted by P. T. Behum and V. P. Girol, made field studies for the U.S. Bureau of Mines (USBM) in the spring and fall of 1977, and in the spring of 1979 , collecting 61 rock samples and 17 panned (heavy-mineral) concentrates of stream sediment for spectrographic, atomic-absorption, and fire-assay analyses and for determinations of graphite and uranium oxide $\left(\mathrm{U}_{3} \mathrm{O}_{8}\right)$ (Gazdik and Dunn, 1982). Analyses were performed at the Bureau of Mines, Reno Research Center, Reno, Nev. The Bureau of Mines, Tuscaloosa Research Center, Tuscaloosa, Ala., evaluated four samples of clay and phyllite for ceramic properties and bloating characteristies.

J. E. Gair and J. F. Slack, assisted at various times by Richard Ketelle, A. E. Grosz, Donald Henry, Ann Stevenson, Thomas Hanley, Gregory Morley, and Timothy Muzik, did field work for the U.S. Geological Survey (USGS) in the spring and fall of 1977 and 1978, and in the fall of 1979. They prepared a reconnaissance geologic map and collected 390 rock-chip and quartz-vein samples, 405 soil samples, and 231 samples of fine-grained stream sediment (Gair and Slack, 1982; Gair, 1982). The samples were analyzed spectrographically and by means of atomic absorption at the USGS laboratories, Denver, Colo. (for Cohutta Wilderness data, see Siems and others, 1979).

\section{Surface- and Mineral-Rights Ownership}

In the Cohutta Wilderness and the Hemp Top Roadless Area all surface rights and about 81 percent of the mineral rights are owned by the U.S. Government. Mineral rights in about 19 percent of the area-6,444 acres in the Cohutta Wilderness and 160 acres in the Hemp Top Roadless Area-are held in perpetuity by private interests (fig. 2). In 1930, large blocks of land were purchased by the U.S. Government from several lumber companies for inclusion in the Chat tahoochee National Forest. Some of the land, now part of the area covered by this report, has mineral rights held by a third party. Legal records of these early transactions are often incomplete and in many such cases mineral rights are probably impossible to establish.

No prospecting permits have been issued by the U.S. Forest Service, and no records of previous mining or prospecting in the study area were found.

\section{GEOLOGY}

The Cohutta Wilderness and the Hemp Top Roadless Area are underlain by sedimentary rocks of the Ocoee Supergroup of Proterozoic $\mathrm{Y}($ ?) and $\mathrm{Z}$ age. Rock units are similar to those in the adjacent Big Frog Wilderness Study Area (Slack and others, in press). The thickness of Ocoee rocks in the area is probably not less than $6,500 \mathrm{ft}(2,000 \mathrm{~m})$, but because of complicated structure and a lack of horizon markers, no approximation of actual thickness can be made. The Ocoee in its type area in the Great Smoky Mountains is $29,000 \mathrm{ft}$ or more thick. Two major subdivisions of the Ocoee, the Snowbird and Great Smoky Groups, are represented by the rocks of the study area. Most of these rocks are slightly metamorphosed graywacke, arkose, sandstone, shale (grading to argillite, slate, and phyllite), siltstone, and pebbly conglomerate. The Snowbird Group consists almost entirely of dark-green and dark-gray to black (carbonaceous) metashale and metasiltstone. Pyrite cubes are abundant in some zones in the Snowbird rocks. The Great Smoky is composed of mixtures of all the rock types of the area, including thin layers similar to rocks in the Snowbird Group. The different kinds of rock are interbedded in layers of less than a foot to hundreds of feet thick. Veins of barren white vein quartz commonly cut the metasedimentary rocks. Metasedimentary beds are lenticular and change substantially in thickness over short distances. Sedimentational features of the rocks suggest deep-water deposition and the action of local turbidity currents during deposition. Repetitions of similar lithologies are commonplace. Because of the lensing of lithologies in rock sequences and the recurrence of similar lithologies at different stratigraphic levels, no beds have been recognizable as horizon markers within the Great Smoky Group. Lithostratigraphic units that have been mapped are defined only as zones of dominant lithologies (Gair and Slack, 1982, maps A and B). The major rock units are interpreted to be separated in places by large thrust faults (Gair and Slack, 1982, map B; and mineral resource potential map accompanying this report). Large folds overturned to the west-northwest occur along the eastern side of the area. The Snowbird and Great Smoky Groups are separated by the major Greenbrier fault in the north part and across much of the west side of the Cohutta Wilderness (Gair and Slack, 1982, map B).

Within rocks in the Great Smoky Group, dominantly sandy and arkosic rocks are named the Panther Bluff Formation in the study area; this formation extends into the Big Frog Wilderness Study Area to the north. The Panther Bluff appears to be overlain by the Boyd Gap Formation, which is composed of interbedded sandy, shaly, silty, and conglomeratic rocks.

\section{GEOCHEMICAL SURVEY}

No metallic deposits are known in the Cohutta Wilderness or the Hemp Top Roadless Area. In our reconnaissance geochemical sampling we found no evidence of mineral deposits or significant mineralization in the area. Scattered high-background concentrations and some slightly anomalous concentrations of trace elements suggest the presence of minor amounts of metal-bearing detrital minerals in the metasedimentary rocks or in small veins.

The geochemical evaluation is based on the traceelement content of 291 samples of rock (chips), 379 samples of soil, and 207 samples of stream sediment collected by the USGS in the Cohutta Wilderness; on the trace-element content of 19,26, and 24 samples, respectively, of similar materials from the Hemp Top Roadless Area (Gair, 1982, figs. 2-4); and on the trace-element content of 40 samples of rock' and 16 panned concentrates of stream sediment collected by the USBM. Trace-element abundances for USGS samples from the wilderness have been listed by Siems and others (1979). Only one geochemically anomalous area has been identified, in the northeast part of the Cohutta Wilderness where high-background concentrations of cobalt and nickel occur in the same general area in samples or rock, soil, and stream sediment (fig. 3). The anomaly is not related to known mineralization and probably does not reflect any significant mineralization in near-surface rocks of the anomalous area.

Trace-element concentrations in the USBM samples are mostly within background ranges established by the USGS data. High concentrations are found in a few scattered veinquartz samples collected by the USBM, but values are only slightly higher than the geochemical background of the country rock and are not considered significant.

Quartz veins of the study area are essentially barren, and their background trace-element abundances are generally lower than those of surrounding rocks (Gair, 1982, table 2). Three panned-concentrate samples were collected in the western part of the wilderness by the USGS. One or two of these samples contain concentrations of beryllium, chromium, lead, nickel, and thorium. Highly magnetic splits of the three samples, separated from the original samples by hand magnet, contain concentrations of tin (Gair, 1982, figs. 4, 9). A few of the other types of samples from the same general area also have small tin concentrations.

\section{OTHER EVALUATIONS}

Seven samples of carbonaceous rocks (phyllite, slate, siltstone) were analyzed for free carbon (graphite), and 12 rock samples were analyzed for uranium $\left(\mathrm{U}_{3} \mathrm{O}_{8}\right)$ in USBM laboratories. The highest carbon content measured was 2.6 percent, and the samples analyzed for uranium contained no detectable $\mathrm{U}_{3} \mathrm{O}_{8}$. 


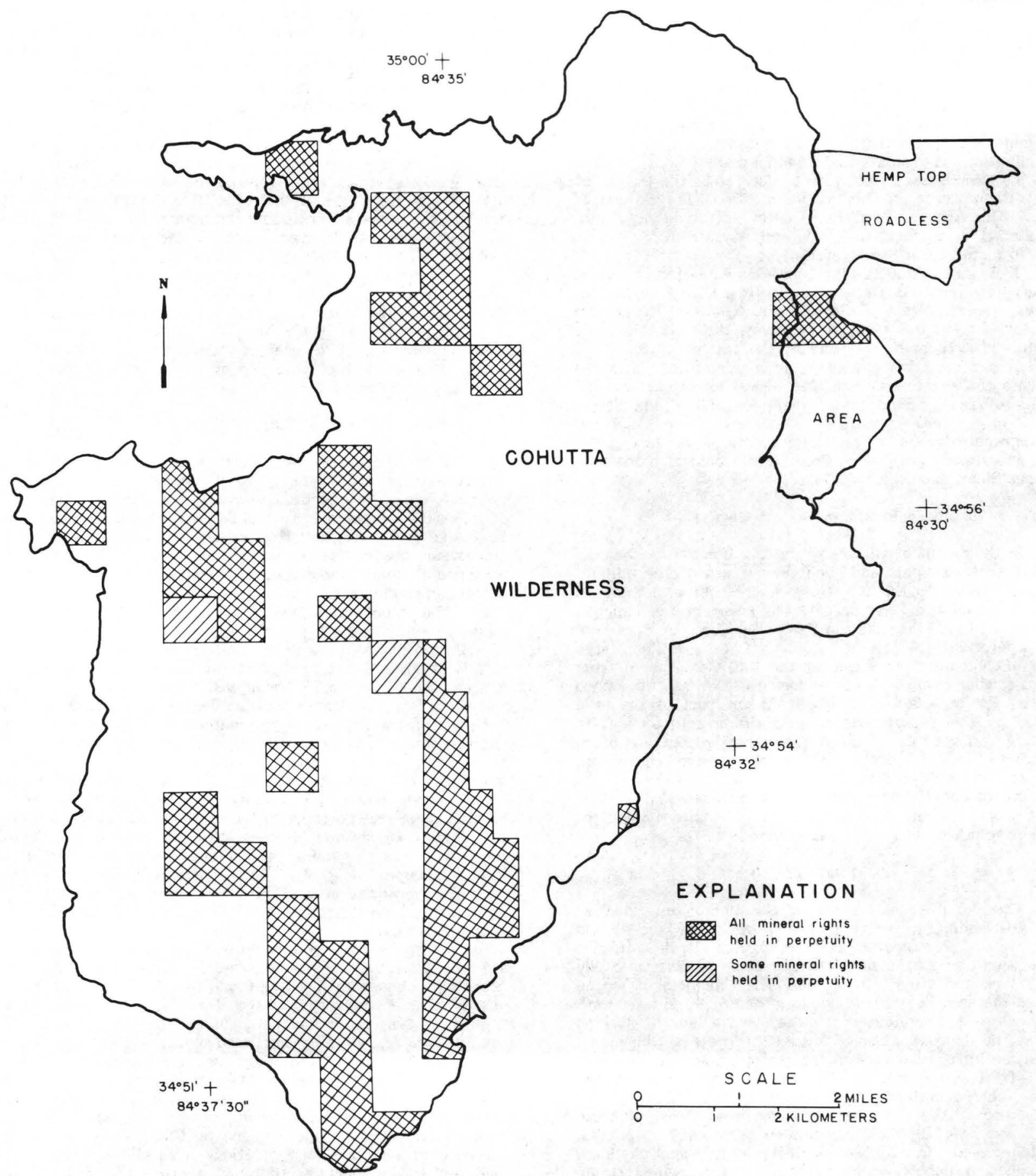

Figure 2.--Map of mineral-rights ownership, Cohutta Wilderness and Hemp Top Roadless Area. Shaded areas have privately owned mineral rights; blank areas have mineral rights held by the U.S. Government. North-south and east-west boundaries of mineral rights areas are based on Georgia land district system. 


\section{MINERAL RESOURCE POTENTIAL}

Rocks in the study area have marginal potential for crushed stone and for raw materials for ceramic products and lightweight aggregate. The potential for tin resources is considered slight because of the low tin concentrations in the geochemical samples, the uncertain source of the tin, and the nature of the geologic terrain. At best, if the tin concentrations detected come from cassiterite in fossil placers in the Ocoee metasedimentary rocks, the resource potential would be low because of the lenticularity of lithologic units which probably would severely limit the extent of placers, and because of the folded terrain which probably would necessitate excessive removal of overburden during development, or underground mining. Copper, gold, iron, manganese, sulfur, and talc have been produced from the surrounding region, 2.5-19 mi outside the boundaries of the wilderness, but apparently no significant potential for these commodities exists in the study area. No geochemical or mineralogical evidence was obtained to support accounts of a few local residents that once silver and tin were produced along Silvermine Creek.

\section{Crushed Stone}

Metasandstone/graywacke has been quarried in the past for local road construction at two sites near the wilderness - at the boundary road on Betty Mountain in the south part of the area, and $1.25 \mathrm{mi}$ east of the boundary on Watson Gap Road (Georgia Route 2). Little possibility exists for reactivation of these quarries or the development of others in the wilderness because road-surfacing material can be trucked from other more easily worked sources in the region at less expense.

\section{Phyllite and Clay}

Phyllite is one of the major rock types of the area, and small amounts of clay are present locally from the weathering of phyllite. Three phyllite samples and one clay sample collected by the USBM were tested for ceramic properties and bloating characteristics. All proved to be at least marginally useful for structural clay products such as building brick. Phyllite samples B-419 and B-429 (for localities see Gair, 1982, fig. 2) bloated, but in the process developed some large pores and remained heavy, limiting the usefulness of the material for lightweight aggregate. The resource potential of phyllite and clay in the study area is low because of these marginal qualities and because of the abundance of similar materials elsewhere in the region.

\section{Tin}

The geochemically anomalous tin in the western part of the Cohutta Wilderness (Gair, 1982, fig. 9) may be derived from fossil placers of cassiterite in the Ocoee rocks, from trace amounts of tin in alluvial and other magnetite, or from unknown exhalative stratabound deposits within the Ocoee rocks. Traces of tin contained in magnetite would have no direct potential value as a mineral resource. Fossil placers and stratabound exhalative deposits could have resource potential, but additional study would be required to identify either placers or layered deposits definitely as the source of the anomalous tin values. The western part if the wilderness can be considered to have only a slight potential for tin, at best.

\section{Other Commodities}

The following mineral commodities are known to occur in the vicinity of the study area, but not within it.

Base-metal sulfides-The Ducktown area, 7.5 - $10 \mathrm{mi}$ northeast of the study area, is one of the major massivesulfide districts of the Appalachian Mountain belt. The district has yielded copper for more than 130 years, sulfur (for making sulfuric acid) for nearly 75 years, and zine for more than 50 years. The Copperhill Formation of Hurst (1955), host rock for the deposits, is at a different stratigraphic position in the Great Smoky Group than are formations in the study area (Wiener and Merschat, 1978). There is no evidence that folds or thrust faults have brought Hurst's Copperhill Formation into the study area, and the paucity of copper and zinc concentrations found during the geochemical survey (Gair, 1982, tables 3,4) suggests that mineralization similar to that of the Ducktown district is absent in the study area. High zinc content was found in two samples from prospect pits (Gair, 1982, table 4-USBM data) and is believed to represent small concentrations of sphalerite in thin quartz veins. The resource potential for massive base-metal sulfide is considered low.

Gold-Gold has been produced $8 \mathrm{mi}$ southwest of the study area, from placer deposits in Murray County, Ga. The source of the Murray County deposits is gold-bearing quartz veins in Fort Mountain Gneiss of Furcron and others (1947), which unconformably underlies the Ocoee Supergroup rocks. Gold has also been produced along Coker Creek and several of its tributaries $19 \mathrm{mi}$ northeast of the area in Monroe County, Tenn. The source of the Coker Creek deposits is gold-bearing quartz veins and disseminated gold in the Ocoee Supergroup (Ashley, 1911; Rove, 1926). According to a local resident, gold was prospected for by means of hydraulic methods on a small tributary of Hickory Creek in the western part of the wilderness prior to establishment of the national forest. This prospect could not be found during the present study. A panned-concentrate sample from Hickory Creek near the reported prospect contains no detectable gold.

All samples collected by the USGS and the USBM in the Cohutta Wilderness and the Hemp Top Roadless Area were analyzed for gold. Most contain no detectable gold; 14 samples contain detectable but unmeasurable amounts of gold; and only 10 rock samples, 6 soil samples, 6 streamsediment samples, and 2 panned-concentrate samples contain measurable amounts of gold-traces (less than $0.1 \mathrm{ppm}$ ) in all samples except four samples of fine-grained stream sediment, the two of panned concentrates, one of rock, and one of soil (Gair, 1982, table 5). In comparison with the evident lack of gold in hundreds of samples, even the small amounts of gold in the relatively few samples in which gold has been detected can be considered anomalous. Such gold-bearing samples are generally widely scattered in the area, and because of their wide spacing, each gold-bearing sample probably represents an isolated gold anomaly and probably an isolated occurrence of gold mineralization. It is not possible from our data to estimate the possible extent of gold mineralization in the areas adjacent to the gold-bearing samples. The gold content of rock and soil samples is demonstrably low, and only a crude estimation can be made of possible gold concentrations in the source rocks of the gold-bearing stream-sediment samples. Low gold concentrations in the stream-sediment samples suggest probable low gold concentrations in the source rocks. However, the small number of gold-bearing streamsediment samples does not provide a very firm basis for such a statistical generalization, and maybe the grade of such samples is generally low simply because these few samples just happen to be relatively far from their source rocks. A very high gold content of $15 \mathrm{ppm}$ found in one pannedconcentrate sample collected by the USBM, but not repeated in a barren panned concentrate from the same locality, probably is derived from a gold-bearing quartz vein. The actual size of such a vein and the grade of gold in the vein are conjectural. The likely small size of most gold-bearing veins in the area and the wide spacing between them, and the likelihood of low gold content in most occurrences suggest virtually no potential for gold resources in the wilderness under forseeable economic conditions. Verification of this rather tentative conclusion or a more optimistic determination of the potential for gold resources would require closely-spaced collecting and analysis of many additional samples from the vicinity of the sites from which the gold-bearing samples were collected during this study. 


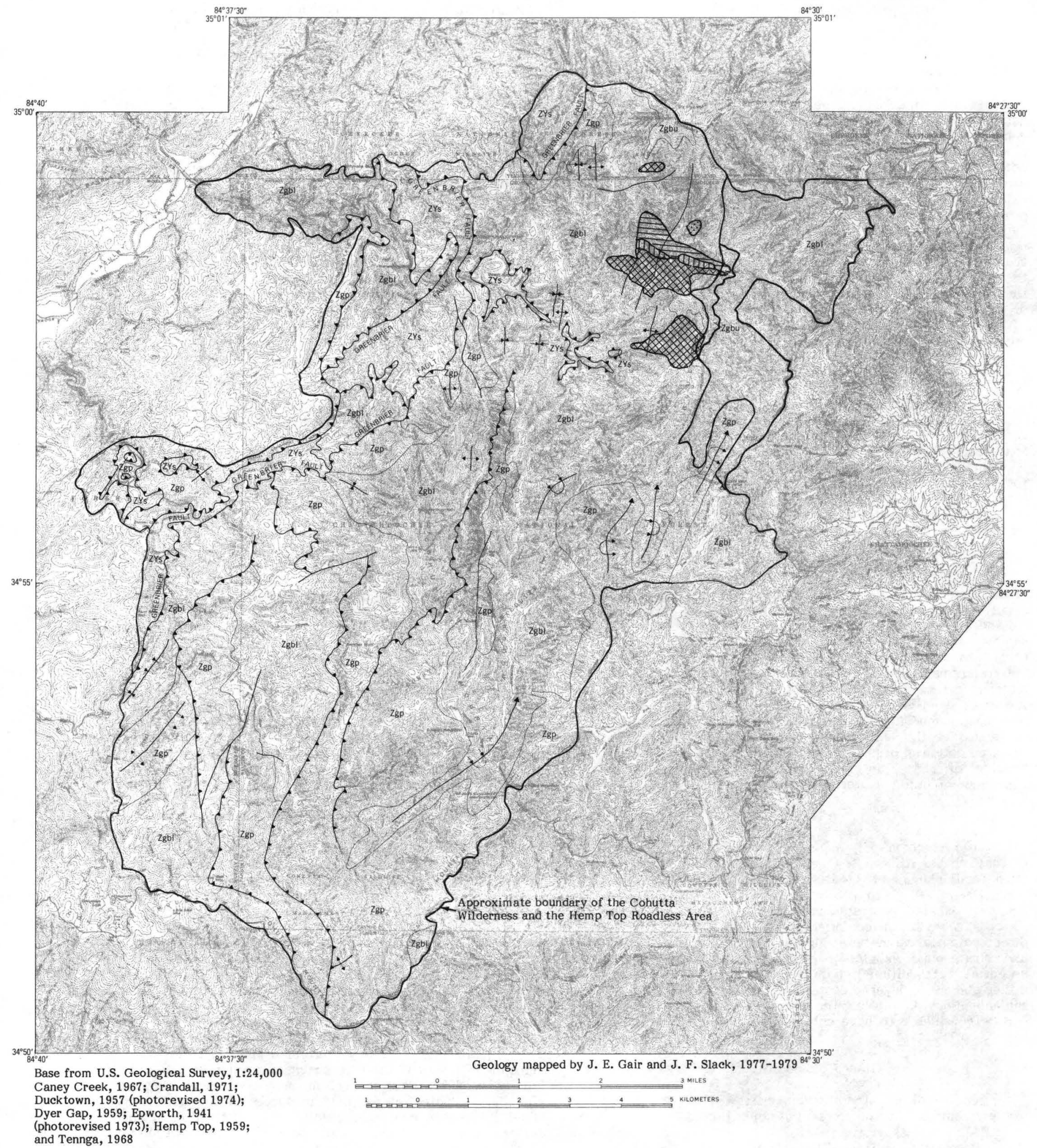

Figure 3.--Areas of overlapping high-background concentrations of cobalt and nickel in rock, soil, and stream-sediment samples. 
DESCRIPTION OF MAP UNITS

Ocoee Supergroup (Proterozoic Z and Y?)

Great Smoky Group (Proterozoic Z)

Zgbu

Zgbl

Zgp
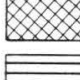

एागाा
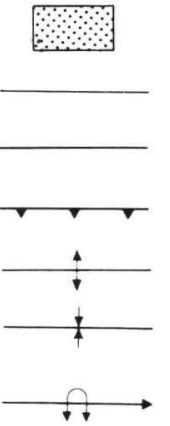

anticline-Showing generalized trace of axial plane at land surface and inferred plunge direction of fold axis

Overturned syncline-Showing generalized trace of axial plane at land surface and plunge direction of fold axis, where inferred 
Table 1.- Analyses for iron and (or) manganese

[Analyzed for iron and manganese by means of atomic absorption methods, for aluminum and silicon by means of semiquantitative spectrographic methods, and for phosphorus by means of Xray fluorescence; all analyses performed by USBM, Reno Metallurgy Center, Reno, Nev.]

\begin{tabular}{|c|c|c|c|c|c|c|c|}
\hline & $\begin{array}{l}\text { amp le } \\
\text { umber } 1\end{array}$ & $\mathrm{Fe}$ & Mn & $\begin{array}{l}P \\
\text { ent }\end{array}$ & $\mathrm{Si}$ & Al & Location \\
\hline B & 407 & 38.1 & 0.11 & 1.5 & 4 & 2 & $\begin{array}{l}\text { Hickory Ridge, } \\
\text { Cohutta Wilderness }\end{array}$ \\
\hline B & 441 & 47.1 & .14 & .35 & 8 & 3 & $\begin{array}{l}\text { Near Popular Camp } \\
\text { Creek, Cohut ta } \\
\text { Wilderness Area }\end{array}$ \\
\hline B & 1 & 13.3 & 9.4 & .59 & $>20$ & 2 & $\begin{array}{l}\text { Green property, } \\
\text { Doogan Mountain } \\
\text { area }\end{array}$ \\
\hline B & 2 & 1.8 & 20.5 & .74 & $>20$ & 2 & $\begin{array}{l}\text { Green property, } \\
\text { Doogan Mountain } \\
\text { area }\end{array}$ \\
\hline B & 3 & 20.7 & 21.7 & 2.6 & 7 & 3 & $\begin{array}{l}\text { Green property, } \\
\text { Doogan Mountain } \\
\text { area }\end{array}$ \\
\hline B & 4 & 1.4 & 37.3 & .16 & .9 & 5 & $\begin{array}{l}\text { Powell property, } \\
\text { Doogan Mountain } \\
\text { area }\end{array}$ \\
\hline B & 5 & 44.8 & .65 & 2.1 & 10 & 1 & $\begin{array}{l}\text { Powell property, } \\
\text { Doogan Mountain } \\
\text { area }\end{array}$ \\
\hline
\end{tabular}

Description of s amp le

Iron-enriched material from prospect pit

Iron-oxide replacement of slate float

Nodules in soil on sides of trench

Pockets of friable manganese-oxides in clay from sides of trench

Manganiferous ironoxide nodules from side of large pit

Manganese-r i ch material from pockets in iron deposits, sample B 5

Massive iron-rich deposit

1 For localities of samples B 407 and B 441 in the Cohutta Wilderness, see Gair, 1982 , fig. 2. 
Iron and manganese-Small amounts of iron and associated manganese were produced in the early 1900s at Doogan Mountain on the west side of the Alaculsy Valley, 2.5 mi west of the wilderness boundary (Watson, 1908). The iron deposits are similar to brown iron ore deposits in nearby parts of Georgia and Tennessee and appear to have formed by replacing clastic or argillaceous metasedimentary rocks within the zone of a major thrust fault bordering the Alaculsy Valley. Iron silicate minerals and iron sulfide disseminated in the "normal" Ocoee rocks of the area presumably were the source of the iron. Analyses of samples from the Doogan Mountain occurrences (table 1; Hull and others, 1919; Haseltine, 1924) show wide variations in the content of iron and manganese, some of which are acceptable ore grades (more than 50 percent iron, for direct shipping; more than 30 percent iron, for ore that is to be beneficiated). The deposits are small and the amounts of undesirable components-silica, phosphorus, and alumina-are consistently too high compared with ores of iron and manganese more readily available elsewhere.

Concentrations of iron oxide similar in appearance and grade and in general types of source rocks to those at Doogan Mountain were found at two localities in the study area (table 1; Gair, 1982, fig. 2). These occurrences are on or close to major inferred faults (Gair and Slack, 1982, Map B); we infer that there may be similar small concentrations of iron and manganese elsewhere in the area along faults cutting the Ocoee rocks. Because of the variable content of iron and manganese in such occurrences, the presence of undesirable constituents, the small size and sporadic distribution of deposits, and the availability of much larger and higher grade deposits elsewhere, the study area is considered to have no resource potential for iron or manganese deposits of this type.

Iron has been produced at Ducktown, Tenn., from gossan formed by the weathering of massive-sulfide deposits and as a by-product of roasting iron sulfides for the manufacture of sulfuric acid. The low potential for massivesulfide deposits in the study area would likewise indicate a low potential for iron from this source.

Graphite-Despite the widespread occurrence of graphitic rocks in the Ocoee Supergroup, the carbon content of such rocks in the study area is low and the resource potential for graphite in nil.

Uranium-The absence of detectable $\mathrm{U}_{3} \mathrm{O}_{8}$ in analyzed samples and the lack of any other evidence of uranium deposits indicate that the study area has no resource potential for uranium.

Talc-Tale deposits are known at Fort Mountain, 7.5 mi southwest of the Cohutta Wilderness. The deposits are associated with rocks not present in the wilderness, and no talc-like material was found in the study area. The study area is considered to have no potential for talc.

Oil and gas-Recent seismic studies (Cook and others, 1979) indicate that the Blue Ridge in North Carolina contains a thick sequence of sedimentary rocks 3,000-15,000 ft thick, below a layer of metamorphic rocks 4,900-45,000 ft thick. These metamorphic rocks, of which those of the Cohutta Wilderness are a part, evidently have been moved $100 \mathrm{mi}$ or more up and over the younger, non-metamorphosed sedimentary rocks. The sedimentary rocks have an unknown potential for hydrocarbons. The depths at which the sedimentary rocks occur and the temperatures implicit in such depths suggest that any hydrocarbons present would be in the form of natural gas (Cook and others, 1979, p. 566). The chances of finding concentrations of such gas are problematical. Although no reasonable estimate of gas potential can be made until deep test drilling is done, the presence of gas cannot be totally discounted.

\section{REFERENCES CITED}

Ashley, G. H., 1911, The gold fields of Coker Creek, Monroe County, Tennessee: Geological Survey of Tennessee, The Resources of Tennessee: v. 1, no. 3, p. 79-107.

Cook, F. A., Albaugh, D. S., Brown, L. D., Kaufman, Sidney, Oliver, J. E., and Hatcher, R. D., Jr., 1979, Thinskinned tectonics in the crystalline southern Appalachians; COCORP seismic-reflection profiling of the Blue Ridge and Piedmont: Geology, v. 7, no. 12, p. 563-567.

Furcron, A. S., 1960, Some lost mineral localities in Georgia: Georgia Mineral Newsletter, v. 13, no. 3, p. 124-129.

Furcron, A. S., Teague, K. H., and Calver, J. L., 1947, Talc deposits of Murray County, Georgia: Georgia Geological Survey Bulletin 53, 75 p.

Gair, J. E., 1982, Geochemical survey of the Cohutta Wilderness and the Hemp Top Roadless Area, northern Georgia and southeastern Tennessee: U.S. Geological Survey Miscellaneous Field Studies Map MF-1415-B, scale 1:48,000 [in press].

Gair, J. E., and Slack, J. F., 1982, Geologic maps of the Cohutta Wilderness and the Hemp Top Roadless Area, northern Georgia and southeastern Tennessee: U.S. Geological Survey Miscellaneous Field Studies Map MF-1415-A, scale 1:48,000 [in press].

Gazdik, G. C., and Dunn, M. L., Jr., 1982, Mineral Resources of Cohutta Wilderness Area, Big Frog Wilderness Study Area, and Hemp Top and Big Frog Additions RARE II Areas, north-central Georgia and southeastern Tennessee: U.S. Bureau of Mines Open-File Report MLA 47-82, 31 p.

Hadley, J. B., and Goldsmith, Richard, 1963, Geology of the eastern Great Smoky Mountains, North Carolina and Tennessee: U.S. Geological Survey Professional Paper 349-B, p. B1-Bll8.

Hale, R. C., 1974, Gold deposits of the Coker Creek district, Monroe County, Tennessee: Tennessee Division of Geology Bulletin 72, 93 p.

Hamilton, W. B., 1962, Geology of the Richardson Cove and Jones Cove quadrangles, Tennessee: U.S. Geological Survey Professional Paper 349-A, p. Al-A55.

Haseltine, R. H., 1924, Iron ore deposits of Georgia: Georgia Geological Survey Bulletin 4l, 222 p.

Fernon, R. M., 1968, Geology of the Ducktown, Isabella, and Persimmon Creek quadrangles, Tennessee and North Carolina: U.S. Geological Survey Open-File Report, 74 p.

Hull, J. P. D., LaForge, Laurence, and Crane, W. R.; 1919, Manganese deposits of Georgia: Georgia Geological Survey Bulletin 35, 146 p.

Hurst, V. J., 1955, Stratigraphy, structure, and mineral resources of the Mineral Bluff quadrangle, Georgia: Georgia Geological Survey Bulletin 63, 137 p. 1973, Geology of the southern Blue Ridge Belt: American Journal of Science, v. 273, no. 8, p. 643-670.

Hurst, V. J., and Crawford, T. J., 1970, Sulfide deposits in the Coosa Valley area, Georgia: Economic Development Administration, U.S. Department of Commerce, $58 \mathrm{p}$.

Hurst, V. J., and Schlee, J. S., 1962, Field excursion, Ocoee metasediments, north-central Georgia-southeast Tennessee: Geological Society of America, Southeastern Section, annual meeting, Guidebook No. $3,28 \mathrm{p}$.

King, P. B., 1964, Geology of the central Great Smoky Mountains, Tennessee: U.S. Geological Survey Professional Paper 349-C, 148 p.

King, P. B., Hadley, J. B., Neuman, R. B., and Hamilton, Warren, 1958, Stratigraphy of Ocoee Series, Great Smoky Mountains, Tennessee and North Carolina: Geological Society of America Bulletin 69, p. 947-966.

Kinkel, A. R., Jr., Feitler, S. A., and Hobbs, R. G., 1968, Copper and sulfur, in U.S. Geological Survey and U.S. Bureau of Mines, Mineral resources of the Appalachian region: U.S. Geological Survey Professional Paper 580, 
p. 377-385.

Magee, Maurice, 1968, Geology and ore deposits of the Ducktown District, Tennessee, in Ridge, J. D., ed., Ore deposits of the United States, 1933-1967 v. 1 (GratonSales volume); New York, American Institute of Mining, Metallurgical, and Petroleum Engineers, p. 207-24l.

Maher, S. W., 1964, The brown iron ores of East Tennessee: Tennessee Division of Geology Report of Investigations $19,63 \mathrm{p}$.

Mellen, James, 1956, Pre-Cambrian sedimentation in the northeast part of Cohutta Mountain quadrangle, Georgia: Georgia Mineral Newsletter, v. 9, no. 2, p. 46-61.

Neuman, R. B., and Nelson, W. H., 1965, Geology of the western Great Smoky Mountains, Tennessee: U.S. Geological Survey Professional Paper 349-D, p. Dl-D81.

Rove, O. N., 1926, Reconnaissance of the gold deposits of Eastern Tennessee: Madison, Wis., University of Wisconsin, unpublished M.S. thesis, $92 \mathrm{p}$.

Safford, J. M., 1856, A geological reconnaissance of the state of Tennessee: Tennessee State Geologist First Biennial Report, 164 p.

1869, Geology of Tennessee: Tennessee Geological
Survey, $550 \mathrm{p}$.

Salisbury, J. W., 1961, Geology and mineral resources of the northwest quarter of the Cohutta Mountain quadrangle: Georgia Geological Survey Bulletin 7l, 61 D.

Siems, D. F., Meier, A. L., Mosier, E. J., and Gair, J. E., 1979, Geochemical data for Cohutta Wilderness, GeorgiaTennessee: U.S. Geological Survey Open-File Report 79-1352, 74 p.

Slack, J. F., Gazdik, G. C., and Dunn, M. L., Jr., in press, Mineral resources of the Big Frog Wilderness Study Area and additions, Polk County, Tennessee, and Fannin County, Georgia: U.S. Geological Survey Bulletin 1531.

Watson, T. L., 1908, A preliminary report on the manganese deposits of Georgia: Georgia Geological Survey Bulletin 14, 195 p.

Wiener, L. S., and Merschat, C. E., 1978, Summary of geology between the Great Smoky Fault at Parksville, Tennessee and basement rocks of the Blue Ridge at Glade Gap, North Carolina, in Milici, R.C., ed., Field trips in the southern Appalachians, April 1978: Tennessee Division Geology Report of Investigations 37, p. 23-29. 